\title{
Influence of E85 ethanol fuel composition on engine oil properties
}

\begin{abstract}
The article presents results of work aimed at determining the influence of hydrocarbon gasoline used to composed E85 ethanol fuel on the properties of engine oil used in spark ignition Flex Fuel automobile engine. For this purpose, two ethanol fuels were composed which consisting of $85 \%(V / V)$ ethanol and 15\% $(V / V)$ conventional hydrocarbon gasoline, which was obtained from two producers. As an object of the study, an engine oil was recommended for this type of engine lubrication, the SAE 5W-30 viscosity grades and ACEA A5/B5 quality grade engine oil was selected. Monitoring of the properties of the subjected oil was carried out before and after 300 hours of engine operation. Test samples of engine oil retained their rheological properties at levels corresponding to their viscosity grade.
\end{abstract}

Key words: E85 ethanol fuel, gasoline, engine oil.

\section{Wpływ składu paliwa etanolowego E85 na właściwości oleju silnikowego}

W artykule przedstawiono wyniki prac, których celem było określenie wypływu zastosowanej benzyny węglowodorowej do komponowania paliwa etanolowego E85 na właściwości oleju silnikowego eksploatowanego w silniku typu flex fuel. W tym celu zestawiono dwa paliwa etanolowe E85 w skład, których wchodziło 85\% (V/V) etanolu oraz 15\% (V/V) benzyny bezołowiowej, którą pozyskano od dwóch producentów. Obiekt badań stanowił olej silnikowy zalecany do smarowania tego rodzaju silników, o klasie lepkości SAE 5W-30 i klasie jakości ACEA A5/B5. Monitorowanie właściwości przedmiotowego oleju prowadzone było przed i po 300 godzinach rzeczywistej pracy silnika. Badane próbki olejów silnikowych zachowały swoje właściwości reologiczne na poziomach odpowiadających ich klasie lepkości.

Słowa klucze: paliwo etanolowe E85, benzyna silnikowa, olej silnikowy.

\section{Introduction}

Properties of engine fuels, from the very beginning of their history, are subject to continual changes related to various factors, like oil price, refinery processes modification, changes of combustion engines design, and conditions related to the environmental protection [20].

The engine petrol (EP), being a blend of liquid hydrocarbons of boiling points ranging from $30^{\circ} \mathrm{C}$ to $215^{\circ} \mathrm{C}$ and improved with a package of additives, is the most popular conventional fuel for spark-ignition (SI) engines. Its composing is carried out in a petroleum processing refinery and consists in qualitative and quantitative selection of hydrocarbon fractions, which takes place in the fuel unit, where components are delivered from refinery chemical processes. Hydrocarbon refinery components include low- and medium-boiling petroleum fractions being products of primary petroleum processing (atmospheric distillation - DRW), light products of secondary processing (cracking, hydrocracking, reforming, isomerization, and alkylation), and also pentane and butane fractions. Those fractions are a blend of various amounts of chemicals containing from 4 to 14 carbon atoms, which can be classified to individual hydrocarbon groups, i.e. saturated hydrocarbons (paraffins, isoparaffins, naphthenes), unsaturated hydrocarbons (olefins, aromas). Also oxygen components are used to produce engine fuels, i.e. ethers and monohydric alcohols, due to which the content of aromatic hydrocarbons, including benzene and olefins, is reduced without simultaneous reduction of final product octane numbers [2, 21].

At the stage of petroleum processing in refineries, in particular in processes of secondary processing, it is possible to shape the composition individual components in such a way, 
that the final fuel formula would have optimal most favourable properties. The development of chemical composition of final ethanol fuels in a refinery is based on the following assumptions:

- final engine fuel is a blend of hydrocarbon fractions and of bioethanol, substantially differing in the chemical composition and properties,

- significant properties of final fuels, comprising the research and motor octane number, fractional composition, vapours pressure, are non-additive,

- economic calculation generating the profit maximisation must be taken into account at the management of hydrocarbon fractions available in the refinery,

- final product must meet the quality requirements [21].

The fuel intended for SI engines should have such properties as to ensure proper formation of the fuel-air blend, proper and knock-free combustion. It should not have an adverse direct or indirect environmental impact, and also it must retain its properties during storage, distribution, and in the fuel system of vehicle's engine. To satisfy the above requirements, the fuel should feature appropriate properties, which can be classified in accordance with the following diagram [2].

In the case of fuels used for SI engines, E85 ethanol fuel is the most commonly used biofuel. It is not a popular fuel on the Polish market, although legally permitted. Regulation of the Minister of Economy of 22 January 2009 [30] concerning the quality requirements for liquid biofuels specified the quality requirements to be met by E85 engine fuel [29].

The legal permit to place E85 ethanol fuel on the market attracted a lot of interest both of bioethanol and of conventional engine fuels producers. The European Union actions are aimed at the reduction of GHG emission level, which was presented in the Directive 2009/28/EC of the European Parliament and of the Council of 23 April 2009 on the promotion of the use of energy from renewable sources $[3,4,27]$. This directive recommends to increase successively the share of energy from renewable sources in fuels used in transport. The increase in the share of energy from renewable sources in fuels used in transport and the requirement to report such actions are the reason for introducing obligatory National Renewable Energy Action Plans. According to the definition provided in the standardisation document CEN/TS 15293:2011 (Automotive fuels. Ethanol (E85) automotive fuel. Requirements and test methods) (replacing the document CEC CWA 15293:2005) this fuel is arranged in practice from two components, i.e. conventional engine petrol $(15 \div 30 \%(V / V))$ of quality corresponding to requirements of the standard EN 228 [29] and bioethanol $(70 \div 85 \%(\mathrm{~V} / \mathrm{V}))$ of quality complying with requirements of the standard EN 15376 [28].

High-ethanol fuel may be used only in cars equipped with factory-adapted engines to operate on such fuels. Such ve- hicles can be fed both with E85 ethanol fuel and with conventional engine petrol and therefore are referred to as Flex Fuel Vehicles (FFV).

E85 ethanol fuel is now most widespread in countries, which to a large extent implement programmes of replacing conventional fuels with fuels obtained from renewable energy sources. They include the USA, Brazil, and Sweden [17].

Ethanol fuels can be composed in two ways. The ethanol fuel can be blended by mixing appropriate amounts of bioethanol and of commercial engine petrol, which in its composition contains a previously dosed package of improvers. The second method consists in introducing basic engine petrol (such that does not contain improvers) to ethanol and then improving the fuel with a package of additives dedicated to such fuels. The package of additives comprises detergent-dispersing additives - additionally working as oxidation and corrosion inhibitors, stabilisers, dyes and markers, aromatic additives, and also metal deactivators [20].

Ethanol fuels comprise ethanol, engine petrol, and a package of improvers at appropriate amounts. Ethanol is obtained by means of a synthetic method as a result of ethylene hydrogenation, but first of all through fermentation, providing an 8 to $15 \%$ water solution of ethanol, containing also admixtures of other alcohols. Pure ethanol (consisting of $96 \%$ of ethanol and $4 \%$ of water) is obtained via distillation. Anhydrous alcohol can be obtained by means of solvent extraction or of azeotropic distillation.

Deposits originate during a flammable mixture combustion in chambers of spark ignition automotive engine [17, 21], partly from the fuel and also due to thermal-oxidising degradation of engine lubricating oil. Components of engine petrol and of lubricating oil are precursors of deposits in combustion chambers, as well as components of those products improver packages [22].

Combustion of so-called "rich" blends, apart from products originating from incomplete combustion, generates the formation of solid particles [17]. Most of created solid combustion products are removed together with the exhaust gas, but some of them deposit on the surface of combustion chambers.

The deposits formation on engine components is strictly related to the hydrocarbon composition of the burned fuel. Aromatic hydrocarbons have the greatest impact on the formation of deposits in combustion chambers [6]. The analysis of deposits shows that they have a molecular structure of a polymeric skeleton [8]. It has from two to four aromatic rings (polynuclear arenes) and is independent of the engine model, in which it originated. However, differences have been observed in the molecular structure of deposit depending on the engine petrol type and on combustion conditions in engine chambers (i.e. heat of combustion, stoichiometric ratio of fuel-air blend, 
engine load etc.). As a result of driving in urban conditions, "stop-and-go" driving, at a smaller speed more deposits are formed than during driving on long sections [17, 21].

Refinery petrol fractions comprise aromatic hydrocarbons containing one or two benzene rings. Arenes are fuel components, which favourably affect the engine power due to a high energy density, which makes that they still constitute a large share in all hydrocarbons existing in the engine petrol. Components originating from secondary petroleum processing (mainly form reforming and catalytic cracking plants) are the source of aromatic hydrocarbons in the final fuel formula. Arenes of high molecular weight (so-called heavy) contribute to the formation of larger deposit amounts in combustion chambers and increase the benzene share in the exhaust gas $[5,21]$.

Deposits forming in combustion chambers cause an increase in the temperature of mixture combustion through the necessity to supply a higher amount of heat to the fuel-air blend and through the slowing down of heat removal from the exhaust gas $[18,19,22]$. Deposits are also the reason for increased compression ratio due to the reduction of combustion chambers volume. All that makes that the engine octane demand grows, which can result in the threat of detonation combustion occurrence.

The reduction of aromatic hydrocarbons content in the petrol has a favourable impact on the engine operation (retaining of combustion chambers clean) and on the reduction of harmful exhaust gas components emission [7, 9-16]. However, on the other hand, in accordance with results of studies [25], the limitation of aromatic hydrocarbons content causes an increased emission of nitrogen oxides $\mathrm{NO}_{x}$.

Stricter requirements related to the emission of harmful substances with the exhaust gas at the shift from EURO 3 to EURO 4 forced manufacturers to reduce the aromatic hydrocarbons content in engine petrol from $42 \%(V / V)$ to $35 \%(V / V)$, which was also considered in objective standards. Also the Worldwide Fuel Charter reduced the permissible aromatic hydrocarbons content to maximum $35 \%(V / V)$, limiting at the same time the distillation end temperature by $15 \div 30^{\circ} \mathrm{C}$ as against the requirements of PN-EN 228 and ASTM D 4814 standard [26], which is the indicator of heavy aromatic hydrocarbons content - originating in the process of catalytic reforming and difficult to burn in conditions of engine operation. The reduction of end boiling point of engine petrol would have to be related with significant reduction of reformates and cracking petrol share. The reduction of distillation end temperature both of reformate and of cracking petrol can be an alternative, which share in the engine petrol is from $60 \%$ to $70 \%$. The total arenes content in engine petrol can be reduced now by the introduction of oxygen compounds, such as ethyl-tert-butyl ether and ethanol.

Light fractions of petrol originating from catalytic cracking contain on average from $25 \%$ to $45 \%$ of olefins, fractions of pyrolytic petrol, in which the content is higher and is approx. $60 \%$. Petrol fractions from catalytic cracking constitute approx. 30 to $45 \%$ of all engine petrol components produced in refineries [24]. Hydrodesulphurisation of fuel fractions and a change of catalytic cracking operation conditions are related to the reduction of olefins content, which in turn results in lowering the octane numbers

Because of the double bonds existence, unsaturated aliphatic hydrocarbons are chemically unstable and show a propensity to form resins and deposits in the engine intake system, in particular on suction valves, which results in increased emission of harmful substances.

The problem of deposits in the intake system was limited due to the application of a new generation of detergent additives to engine petrol. However, such substances get to the engine combustion chamber and there they deposit on the cylinder head, piston head, and on piston rings [21].

PN-EN 228 reduced the olefins content to a level of $18 \%(V / V)$. In turn, the Worldwide Fuel Charter for fuels in category 3 and 4 permits their content maximum to $10 \%(V / V)$. Such a significant reduction of unsaturated aliphatic hydrocarbons in the formula of engine petrol means a reduction of components originating from catalytic cracking and pyrolysis.

Alkylate $\left(\mathrm{C}_{4}-\mathrm{C}_{5}\right)$ and isomerizate $\left(\mathrm{C}_{5}-\mathrm{C}_{6}\right)$ are high-octane components of engine petrol and their total share in the final fuel formula is approx. $30 \%$. Because of the reduction of aromatic hydrocarbons content, it will be justified to increase the share of both those fractions content, as well as of oxygen compounds, such as ethers and alcohols, but due to the reduction of vapours pressure, also their content will be limited $[1,23]$.

\section{Test assumptions}

Tests were aimed at determination of the influence of applied hydrocarbon petrol included in E85 ethanol fuel on selected physicochemical and practical properties of engine lubricating oil.

The laboratory tests were carried out on a fully synthetic engine lubricating oil of SAE 5W-30 viscosity class and ACEA A5/B5 quality class, satisfying requirements of Ford
WSS-M2C913-C, designed for lubrication of flex fuel type car spark ignition engines.

The engine lubricating oil was tested on an engine research-test bed Ford 1.8L Duratec-HE PFI FFV (125 PS) MI4 (Euro IV), factory-adapted to feed fuel containing from $0 \%(V / V)$ to $85 \%(V / V)$ ethanol (flex fuel type engine). Tests were carried out in accordance with the testing procedure, for 
which a 4-phase repeatable test cycle was adopted, constituting an engine test. Such method of proceeding is predicted in numerous test procedures, including those developed under the CEC and is intended to reflect average engine operating conditions during a vehicle operation in low-volume urban traffic. Based on own experience an assumption was made that tests will be carried out during $300 \mathrm{~h}$ of actual engine operation (each $100 \mathrm{~h}$ of engine operation corresponds to a mileage of $6000 \mathrm{~km}$ under actual operation conditions), because such a period of operation would allow to observe processes of multidirectional engine oil degradation. It should be performed with breaks (like in the case of actual vehicle

Table 1. Properties of unleaded 95 petrols declared by the producer

\begin{tabular}{|c|c|c|c|c|c|c|}
\hline \multirow[t]{2}{*}{ Properties } & \multirow[t]{2}{*}{ Unit } & \multicolumn{2}{|c|}{ Measurement result } & \multicolumn{2}{|c|}{$\begin{array}{l}\text { Requirements acc. to } \\
\text { PN-EN 228:2013-04 } \\
\text { standard }\end{array}$} & \multirow[t]{2}{*}{ Test method } \\
\hline & & producer A & producer B & $\min$. & $\max$ & \\
\hline Research octane number, RON & - & 95.2 & 95.8 & 95.0 & - & PN-EN ISO 5164 \\
\hline Motor octane number, MON & - & 86.3 & 85.4 & 85.0 & - & PN-EN ISO 5163 \\
\hline Lead content & $\mathrm{mg} / \mathrm{l}$ & less than 2.5 & less than 2.5 & - & 5.0 & PN-EN 237 \\
\hline Density at $15^{\circ} \mathrm{C}$ & $\mathrm{kg} / \mathrm{m}^{3}$ & 739.5 & 733.9 & 720.0 & 775.0 & $\begin{array}{l}\text { PN-EN ISO } 3675 \\
\text { PN-EN ISO } 12185\end{array}$ \\
\hline Sulphur content & $\mathrm{mg} / \mathrm{kg}$ & 1.3 & 9.1 & - & 10.0 & $\begin{array}{l}\text { PN-EN ISO } 13032 \\
\text { PN-EN ISO } 20846 \\
\text { PN-EN ISO } 20884\end{array}$ \\
\hline Manganese content & $\mathrm{mg} / 1$ & less than 0.20 & less than 2.0 & - & 2.0 & $\begin{array}{l}\text { PN-EN } 16135 \\
\text { PN-EN } 16136 \\
\end{array}$ \\
\hline Induction period & minutes & above 360 & above 360 & 360 & - & PN-EN ISO 7536 \\
\hline Resins content (after washing with solvent) & $\mathrm{mg} / 100 \mathrm{ml}$ & 1 & 1 & - & 5 & PN-EN ISO 6246 \\
\hline $\begin{array}{l}\text { Test of corrosive action on a copper plate } \\
\left(3 \mathrm{~h} \text { at temperature of } 50^{\circ} \mathrm{C}\right)\end{array}$ & class & 1 & 1 & \multicolumn{2}{|c|}{ class 1} & PN-EN ISO 2160 \\
\hline Appearance & - & $\begin{array}{l}\text { clear and } \\
\text { transparent }\end{array}$ & $\begin{array}{l}\text { clear and } \\
\text { transparent }\end{array}$ & \multicolumn{2}{|c|}{ clear and transparent } & visual inspection \\
\hline $\begin{array}{l}\text { Content of hydrocarbons, type: } \\
\text { - olefins } \\
\text { - arenes }\end{array}$ & $\%(V / V)$ & $\begin{array}{r}1.0 \\
31.6 \\
\end{array}$ & $\begin{array}{l}12.5 \\
24.6\end{array}$ & - & $\begin{array}{l}18.0 \\
35.0\end{array}$ & $\begin{array}{c}\text { PN-EN } 15553 \\
\text { PN-EN ISO } 22854\end{array}$ \\
\hline Benzene content & $\%(V / V)$ & 0.75 & 0.58 & - & 1.00 & $\begin{array}{c}\text { PN-EN } 238 \\
\text { PN-EN } 12177 \\
\text { PN-EN ISO } 22854 \\
\end{array}$ \\
\hline Oxygen content & $\%(m / m)$ & 1.80 & 2.42 & - & 3.7 & $\begin{array}{c}\text { PN-EN } 1601 \\
\text { PN-EN } 13132 \\
\text { PN-EN } 22854 \\
\end{array}$ \\
\hline $\begin{array}{l}\text { Oxygen compounds content: } \\
\text { - methanol } \\
\text { - ethanol } \\
\text { - isopropyl alcohol } \\
\text { - isobutyl alcohol } \\
\text { - tert-butyl alcohol } \\
\text { - ethers (with } 5 \text { or more carbon atoms) } \\
\text { - other oxygen compounds }\end{array}$ & $\%(V / V)$ & $\begin{array}{l}0.0 \\
4.7 \\
0.0 \\
0.0 \\
0.0 \\
1.1 \\
0.0\end{array}$ & $\begin{array}{l}\text { less than } 0.17 \\
\quad 4.80 \\
\text { less than } 0.17 \\
\text { less than } 0.17 \\
\text { less than } 0.17 \\
\quad 3.40 \\
\text { less than } 0.17\end{array}$ & $\begin{array}{l}- \\
- \\
- \\
- \\
- \\
- \\
-\end{array}$ & $\begin{array}{r}3.0 \\
10.0 \\
12.0 \\
15.0 \\
15.0 \\
22.0 \\
15.0\end{array}$ & $\begin{array}{c}\text { PN-EN } 1601 \\
\text { PN-EN } 13132 \\
\text { PN-EN ISO } 22854\end{array}$ \\
\hline Vapour pressure & $\mathrm{kPa}$ & 79.0 & 83.0 & 45.0 & 90.0 & PN-EN 13016:1 \\
\hline $\begin{array}{l}\text { Fractional composition: } \\
\text { - distils up to } 70^{\circ} \mathrm{C} \\
\text { - distils up to } 100^{\circ} \mathrm{C} \\
\text { - distils up to } 150^{\circ} \mathrm{C} \\
\text { - distillation end } \\
\text { - distillation residue }\end{array}$ & $\begin{array}{c}\%(V / V) \\
\%(V / V) \\
\%(V / V) \\
{ }^{\circ} \mathrm{C} \\
\%(V / V)\end{array}$ & $\begin{array}{c}43.5 \\
57.9 \\
90.9 \\
188.0 \\
1.0\end{array}$ & $\begin{array}{c}45.7 \\
62.2 \\
88.5 \\
191.3 \\
1.2\end{array}$ & $\begin{array}{l}20.0 \\
46.0 \\
75.0 \\
- \\
- \\
\end{array}$ & $\begin{array}{c}50.0 \\
71.0 \\
- \\
210.0 \\
2.0\end{array}$ & PN-EN ISO 3405 \\
\hline Volatility index & - & 1109 & 1150 & - & 1150 & $\begin{array}{l}\text { PN-EN } 228 \\
\text { (Table 2) }\end{array}$ \\
\hline
\end{tabular}


operation in a city on a long distance). So it was determined, mation of lubricating oil operating condition (in this case that the engine would operate non-stop $16 \mathrm{~h}$ per day and it - thermal) to such, which occur during an actual vehicle would be stopped for $8 \mathrm{~h}$ for cooling - for further approxi- operation.

Table 2. Properties of ethanol declared by the producer

\begin{tabular}{|c|c|c|c|c|c|}
\hline \multirow{2}{*}{ Properties } & \multirow[t]{2}{*}{ Unit } & \multirow{2}{*}{$\begin{array}{c}\begin{array}{c}\text { Measurement } \\
\text { result }\end{array} \\
\text { EtOH }\end{array}$} & \multicolumn{2}{|c|}{$\begin{array}{l}\text { Requirements of PN-EN } \\
15376: 2014-11 \text { standard }\end{array}$} & \multirow{2}{*}{ Test method } \\
\hline & & & $\min$. & $\max$ & \\
\hline Ethanol content + higher saturated alcohols & $\%(m / m)$ & 99.852 & 98.7 & - & PN-EN 15721 \\
\hline Content of higher saturated $\left(\mathrm{C}_{3}-\mathrm{C}_{5}\right)$ monohydric alcohols & $\%(m / m)$ & less than 0.001 & - & 2.000 & PN-EN 15721 \\
\hline Methanol content & $\%(m / m)$ & less than 0.001 & - & 1.000 & PN-EN 15721 \\
\hline Water content & $\%(m / m)$ & 0.137 & - & 0.300 & PN-EN 15489 \\
\hline Total acidity (expressed as acetic acid content) & $\%(m / m)$ & 0.004 & - & 0.007 & PN-EN 15491 \\
\hline Conductance & $\mu \mathrm{S} / \mathrm{cm}$ & - & - & 2.5 & PN-EN 15938 \\
\hline Appearance & - & $\begin{array}{l}\text { transparent, void } \\
\text { of pollutants }\end{array}$ & \multicolumn{2}{|c|}{$\begin{array}{c}\text { transparent } \\
\text { and colourless }\end{array}$} & PN-EN 15769 \\
\hline Inorganic chlorides content & $\mathrm{mg} / \mathrm{kg}$ & less than 4.0 & - & 1.500 & PN-EN 15492 \\
\hline Sulphate content & $\mathrm{mg} / \mathrm{kg}$ & - & - & 3.000 & PN-EN 15492 \\
\hline Copper content & $\mathrm{mg} / \mathrm{kg}$ & less than 0.070 & - & 0.100 & PN-EN 15488 \\
\hline Phosphorus content & $\mathrm{mg} / \mathrm{l}$ & less than 0.15 & - & 0.15 & PN-EN 15487 \\
\hline Dry residue content after evaporation & $\mathrm{mg} / 100 \mathrm{ml}$ & less than 10 & - & 10 & PN-EN 15691 \\
\hline Sulphur content & $\mathrm{mg} / \mathrm{kg}$ & less than 5.0 & - & 10.0 & PN-EN 15486 \\
\hline
\end{tabular}

Table 3. Properties of E85 ethanol fuel composed using commercial petrols originating from two different suppliers

\begin{tabular}{|c|c|c|c|c|c|c|}
\hline \multirow[t]{2}{*}{$\begin{array}{l}\text { Determined property } \\
\text { Test conditions }\end{array}$} & \multirow[t]{2}{*}{ Unit } & \multicolumn{2}{|c|}{ Measurement result } & \multicolumn{2}{|c|}{$\begin{array}{l}\text { Requirements acc. } \\
\text { to PKN-CEN/TS } \\
\text { 15293:2012 standard }\end{array}$} & \multirow[t]{2}{*}{ Test method acc. to } \\
\hline & & $\mathrm{E} 85 / \mathrm{L} / \mathrm{TE} / 17$ & $\mathrm{E} 85 / \mathrm{O} / \mathrm{TE} / 17$ & $\min$ & $\max$ & \\
\hline Density at $15^{\circ} \mathrm{C}$ & $\mathrm{kg} / \mathrm{m}^{3}$ & 786.2 & 785.9 & 760.0 & 800.0 & PN-EN ISO 12185 \\
\hline Induction period & $\min$. & $>360$ & $>360$ & 360 & - & PN-EN ISO 7536 \\
\hline Corrosive action on copper & class & $1 \mathrm{a}$ & $1 \mathrm{a}$ & \multicolumn{2}{|c|}{1} & PN-EN ISO 2160 \\
\hline $\begin{array}{l}\text { Resins content } \\
\text { (after washing with solvent) }\end{array}$ & $\mathrm{mg} / 100 \mathrm{ml}$ & $<1$ & $<1$ & - & 5 & PN-EN ISO 6246 \\
\hline $\begin{array}{l}\text { Total acidity } \\
\text { (converted to acetic acid) }\end{array}$ & $\%(m / m)$ & 0.002 & 0.003 & - & 0.005 & PN-EN ISO 15491 \\
\hline Conductance & $\mu \mathrm{S} / \mathrm{cm}$ & 0.86 & 0.74 & - & 1.50 & PN-EN 15938 \\
\hline Water content & $\mathrm{mg} / \mathrm{kg}$ & 350 & 331 & - & 400 & PN-EN 15489 \\
\hline Copper content & $\mathrm{mg} / \mathrm{kg}$ & $<0.10$ & $<0.10$ & & & \multirow{2}{*}{ PN-EN 15837} \\
\hline Phosphorus content & $\mathrm{mg} / \mathrm{l}$ & $<0.15$ & $<0.15$ & - & 0.15 & \\
\hline Sulphur content & $\mathrm{mg} / \mathrm{kg}$ & $<3$ & $<3$ & - & 10.0 & PN-EN 20846 \\
\hline Inorganic chlorides content & $\mathrm{mg} / \mathrm{kg}$ & $<2.0$ & $<2.0$ & - & 1.2 & \multirow{2}{*}{$\begin{array}{l}\text { proprietary method based on } \\
\text { Annex A to standard PKN- } \\
\text { CEN/TS } 15293 \text { para. A4 } \\
\text { (extraction to water phase) }\end{array}$} \\
\hline Sulphates content & $\mathrm{mg} / \mathrm{kg}$ & $<0.9$ & $<0.9$ & - & 2.6 & \\
\hline \multirow{2}{*}{ Ethanol content } & \multirow{2}{*}{$\%(V / V)$} & \multirow{2}{*}{85.8} & \multirow{2}{*}{85.2} & \multicolumn{2}{|c|}{ climate class a } & \multirow{2}{*}{ PN-EN 1601} \\
\hline & & & & 70 & 85 & \\
\hline \multirow{2}{*}{ Vapour pressure } & \multirow{2}{*}{$\mathrm{kPa}$} & \multirow{2}{*}{43.6} & \multirow{2}{*}{38.3} & clim & ass a & \multirow{2}{*}{ PN-EN 13016:1 } \\
\hline & & & & 35.0 & 60.0 & \\
\hline
\end{tabular}


The study comprised two tests on an engine test-bed, which was fed with two E85 ethanol fuels composed in the INiG - PIB laboratory, differing in the type of commercial hydrocarbon petrol used to compose them. The component composition of prepared E85 ethanol fuels is provided below:

- fuel 1: $85 \%(V / V)$ of engine ethanol $+15 \%(V / V)$ of commercial engine petrol from producer A;

- fuel 2: $85 \%(V / V)$ of engine ethanol + 15\% $(V / V)$ of commercial engine petrol from producer $\mathrm{B}$.
Table 1 specifies properties of engine unleaded petrol 95 declared by producers, while Table 2 - properties of ethanol being the main component of E85 ethanol fuels.

Table 3 presents results of tests on properties of E85 ethanol fuels composed in INiG-PIB, utilising petrol originating from two producers, and also results of tests on the ethanol content and on the vapour pressure referred to climate requirements in accordance with PKN-CEN/TS 15293:2012 standard [25].

\section{Discussion of obtained test results}

In accordance with the current state of knowledge the quality of engine lubricating oil can be determined through tests, comprising a laboratory assessment of physicochemical properties, such as the kinematic viscosity determined at a temperature of $40^{\circ} \mathrm{C}$ and $100^{\circ} \mathrm{C}$, dynamic viscosity HTHS, structural viscosity CCS determined at a temperature of $-30^{\circ} \mathrm{C}$ among rheological properties, and the acid number and total base number, non-soluble matter content, oxidation, nitration, and sulphonation degree, oxidation resistance, and the content of elements comprised by the package of improvers, originating from the wear and from external pollution - in the field of degradation degree determination. During the operation the engine lubricating oil in question was exposed to the action of various factors, resulting in a gradual loss of certain practical and operating properties. The obtained results of tests were analysed in view of possible reasons for physicochemical parameters changes during tests on an engine test bed of a Flex Fuel type engine.

The engine oil marked as sample 1 was collected after $300 \mathrm{~h}$ of engine operation, fuelled with E85 ethanol fuel denoted as fuel 1 . In turn, the oil marked as sample 2 was collected after the engine test, during which the engine was fuelled with fuel 2. Table 4 presents results of tests obtained for fresh engine lubricating oil Ford Formuła F in SAE 5W-30 viscosity class and for samples of the considered oil after various periods of operation in a FLEX FUEL type engine.

The examined engine oil samples taken after $300 \mathrm{~h}$ of engine operation retained their rheological properties on permissible levels. The kinematic viscosity of those samples was determined at temperatures of $40^{\circ} \mathrm{C}$ and $100^{\circ} \mathrm{C}$. In sample 1 it slightly increased (by approx. $5 \%$ at $40^{\circ} \mathrm{C}$ and by approx. $4 \%$ at $100^{\circ} \mathrm{C}$ ) as against appropriate initial values determined for the sample of a fresh oil. The kinematic viscosity at both temperatures increased probably from oxidation processes during the operation, resulting in the formation of degradation products of engine lubricating oil. In the case of oil 2 sample the value of determined kinematic viscosity at temperatures of $40^{\circ} \mathrm{C}$ and $100^{\circ} \mathrm{C}$ remained on a nearly unchanged level (Figures 1, 2).

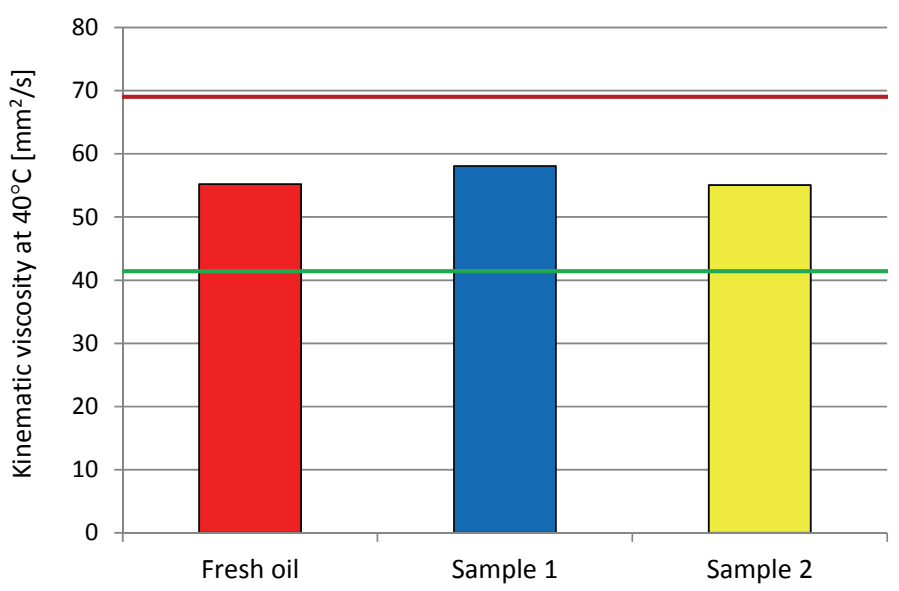

Fig. 1. Change of kinematic viscosity at $40^{\circ} \mathrm{C}$ for tested samples of SAE 5W-30 engine oil (green line - lower limit, red line - upper limit)

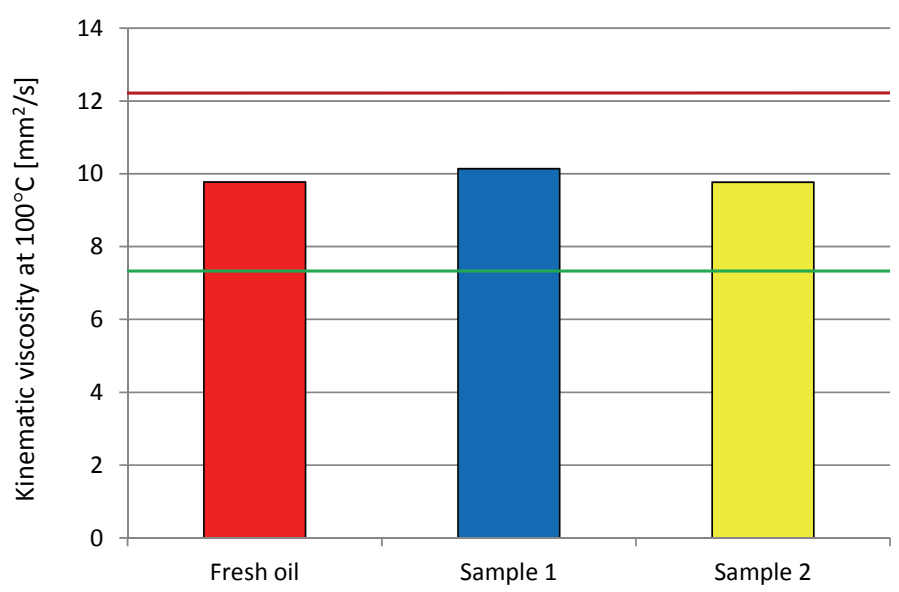

Fig. 2. Change of kinematic viscosity at $100^{\circ} \mathrm{C}$ for tested samples of SAE 5W-30 engine oil (green line - lower limit, red line - upper limit)

In the case of dynamic viscosity HTHS determination the determined values declined, in the case of sample 1 to a level of $3.0 \mathrm{mPa} \cdot \mathrm{s}$ (a decline by approx. $21 \%$ as against the fresh oil), and for sample 2 to a level of $3.18 \mathrm{mPa} \cdot \mathrm{s}$ (a decline by approx. $16 \%$ ). However, those values fall within the range permissible for this viscosity class (above $2.9 \mathrm{mPa} \cdot \mathrm{s}$ ). This confirms 
retaining by the tested samples of the engine oil the lubricating functions of frictional connections in the engine under conditions of high temperature and at high shear rates (Figure 3 ).

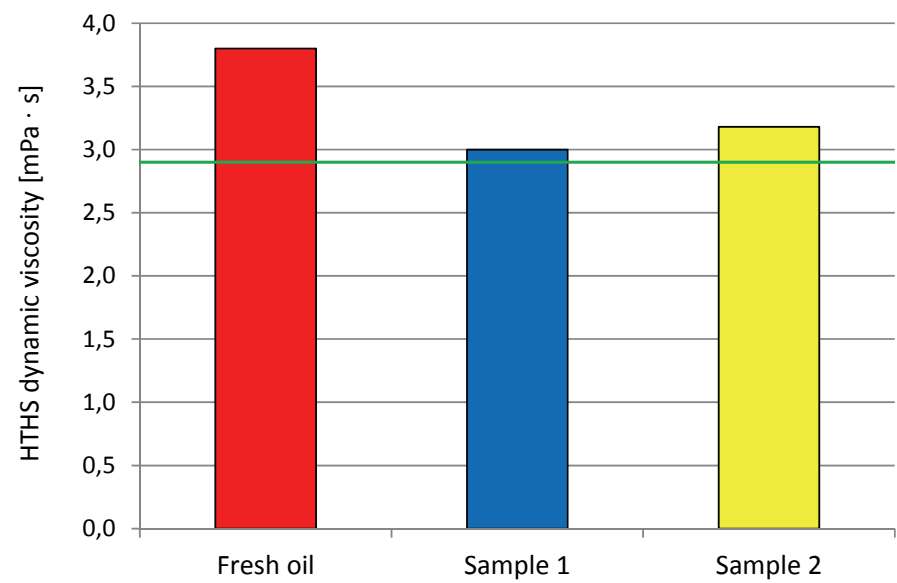

Fig. 3. Change of dynamic viscosity for SAE $5 \mathrm{~W}-30$ engine oil samples (green line - minimum limit value)

At the same time for the studied sample of the oil in question the structural viscosity $\mathrm{CCS}$ was determined at $-30^{\circ} \mathrm{C}$. For sample 1 this parameter increased by approx. $73 \%$, and for sample 2 by approx. $52 \%$ against the value determined for the fresh oil. However, these values do not exceed the permissible limit value for this viscosity class, equal to $6600 \mathrm{mPa} \cdot \mathrm{s}$. This proves the fact that at a start of a cold or under negative temperatures engine the oil in a liquid form will reach in a short time, without disturbances, the moving connections of the engine (Figure 4).

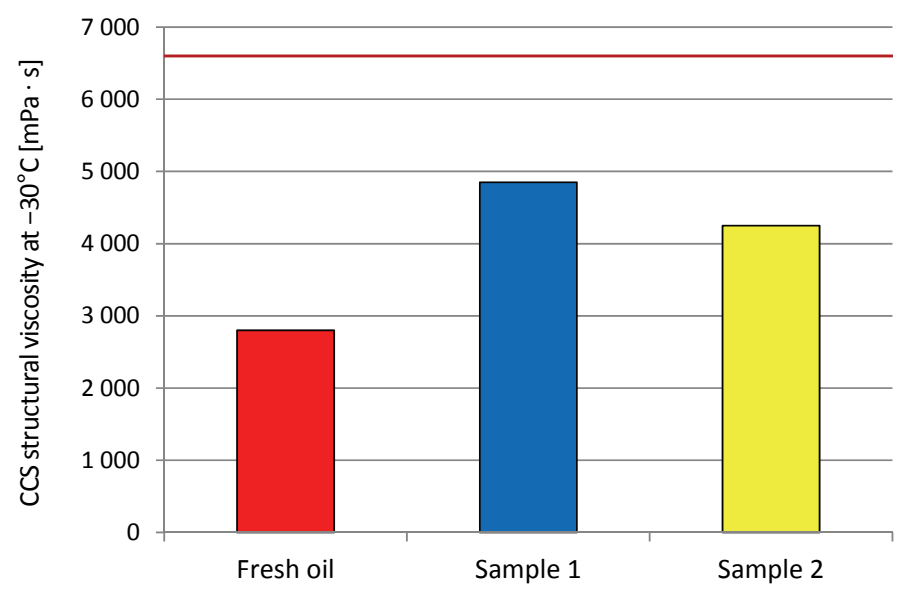

Fig. 4. Change of structural viscosity at $-30^{\circ} \mathrm{C}$ for SAE $5 \mathrm{~W}-30$ engine oil samples (red line - maximum limit value)

The amount of products formed as a result of degradation processes due to oxidation, sulphonation, and nitration increased to a level of - for sample $1-13.3 \mathrm{~A} / \mathrm{cm}, 16.5 \mathrm{~A} / \mathrm{cm}$, and $9.6 \mathrm{~A} / \mathrm{cm}$, respectively, and for sample $2-9.6 \mathrm{~A} / \mathrm{cm}, 12.1 \mathrm{~A} / \mathrm{cm}$, and $4.7 \mathrm{~A} / \mathrm{cm}$. The determined levels prove that the degradation of the engine lubricating oil was insignificant (Figure 5).
This is also confirmed by the levels of substances insoluble in n-pentane and toluene determined at low levels (Table 4).

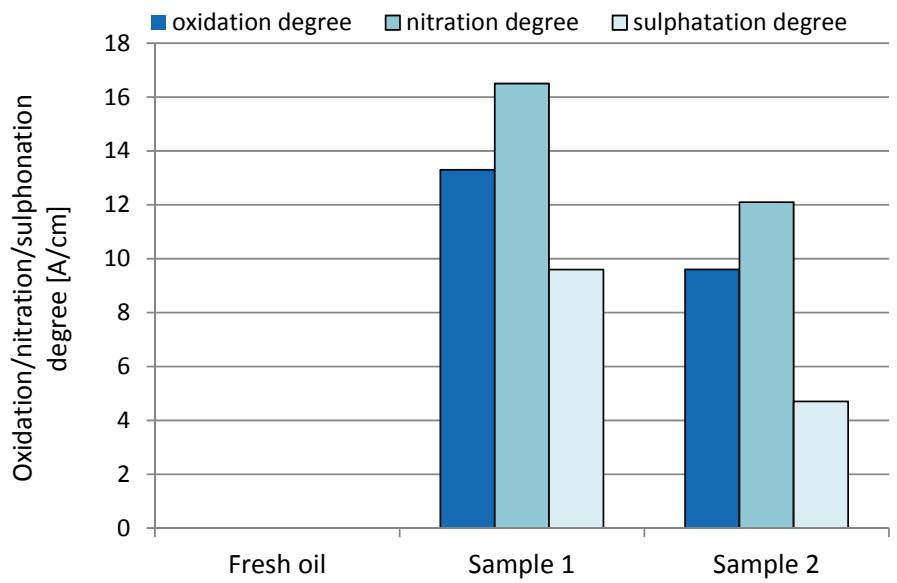

Fig. 5. Change of oxidation, nitration, and sulphonation degree for SAE 5W-30 engine oil samples

The antioxidant content was determined by means of two research methods. Indirectly by the determination of engine oil oxidising stability by means of a modified research method ASTM D 4742 [23] and directly by the determination by means of ICP-OES method of the zinc content, which is included in the elemental composition of the applied antioxidant. The modification of ASTM 4742 method consisted in replacing the normative fuel component, being the diesel oil, with E85 ethanol fuel consisting of $85 \%(V / V)$ of fuel ethanol and of $15 \%(V / V)$ of basic hydrocarbon petrol.

On the basis of obtained oxidising stability results it is possible to state that for both tested samples there was a significant decrease of its value, below permissible critical value (maximum permissible decline by $25 \%$ against the value determined for the sample of fresh oil), for sample 1 - by approx. 55\%, and for sample 2 - by approx. 57\% against the value of 364 determined for the initial sample of the engine oil (Figure 6).

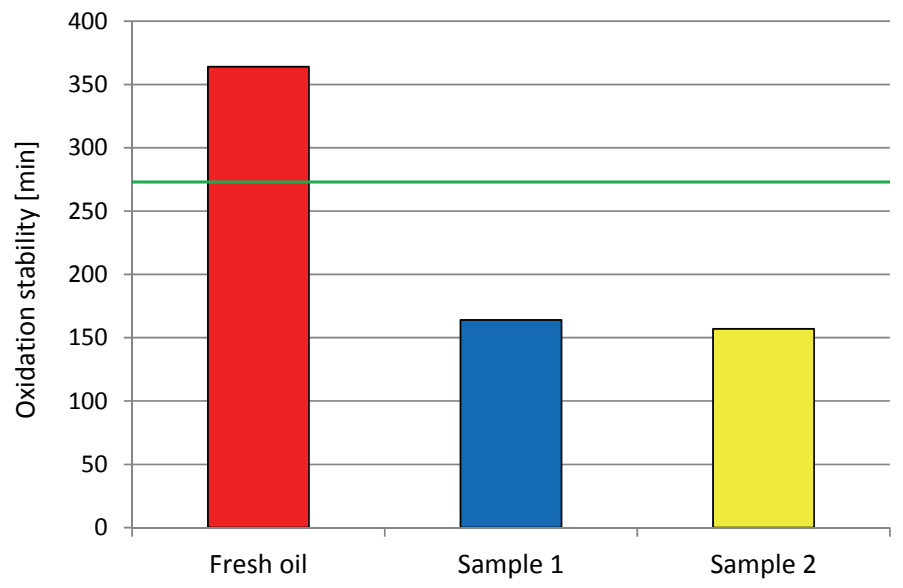

Fig. 6. Change of oxidation resistance for SAE $5 \mathrm{~W}-30$ engine oil samples (green line - minimum limit value) 
Table 4. Results of physicochemical properties tests of SAE 5W-30 engine lubricating oil during tests on an engine test bed of a Flex Fuel type engine fed with ethanol fuels

\begin{tabular}{|c|c|c|c|c|c|}
\hline Determined property & Unit & Fresh oil & Sample 1 & Sample 2 & Test method \\
\hline Kinematic viscosity at $40^{\circ} \mathrm{C}$ & $\mathrm{mm}^{2} / \mathrm{s}$ & 55.22 & 58.08 & 55.06 & PN-EN ISO 3104 \\
\hline Kinematic viscosity at $100^{\circ} \mathrm{C}$ & $\mathrm{mm}^{2} / \mathrm{s}$ & 9.774 & 10.14 & 9.770 & PN-EN ISO 3104 \\
\hline Viscosity index & - & 164 & 163 & 164 & PN-ISO 2909 \\
\hline $\begin{array}{l}\text { HTHS dynamic viscosity } \\
\text { (at } 150^{\circ} \mathrm{C} \text { and at shear rate of } 10^{6} \mathrm{~s}^{-1} \text { ) }\end{array}$ & $\mathrm{mPa} \cdot \mathrm{s}$ & 3.80 & 3.00 & 3.18 & PN-C-04098 \\
\hline Structural viscosity at $-30^{\circ} \mathrm{C} \mathrm{CCS}$ method & $\mathrm{mPa} \cdot \mathrm{s}$ & 2800 & 4850 & 4250 & PN-C-04150 \\
\hline Total base number & $\mathrm{mg} \mathrm{KOH} / \mathrm{g}$ & 11.1 & 8.2 & 7.8 & PN-C-04163 \\
\hline Acid number & $\mathrm{mg} \mathrm{KOH} / \mathrm{g}$ & 2.8 & 3.4 & 3.6 & PN-C-04049 \\
\hline Ethanol content & $\%(m / m)$ & $<0.005$ & $\begin{array}{c}0.01 \\
(94 \mathrm{mg} / \mathrm{kg})\end{array}$ & $\begin{array}{c}<0.005 \\
(1.4 \mathrm{mg} / \mathrm{kg})\end{array}$ & $\begin{array}{l}\text { high-temperature gas } \\
\text { chromatography technique }\end{array}$ \\
\hline $\begin{array}{l}\text { Insoluble deposits content: } \\
\text { - in pentane } \\
\text { - in toluene }\end{array}$ & $\%(m / m)$ & $\begin{array}{l}0.000 \\
0.000\end{array}$ & $\begin{array}{l}0.23 \\
0.04\end{array}$ & $\begin{array}{l}0.00 \\
0.00\end{array}$ & ASTM D 893 \\
\hline Oxidation degree & \multirow{3}{*}{$\mathrm{A} / \mathrm{cm}$} & 0.0 & 13.3 & 9.6 & \multirow{3}{*}{ ASTM E 2412} \\
\hline Nitration degree & & 0.0 & 16.5 & 12.1 & \\
\hline Sulphonation degree & & 0.0 & 9.6 & 4.7 & \\
\hline Soot content & $\%(m / m)$ & less than 0.1 & less than 0.1 & less than 0.1 & DIN 51452 \\
\hline Oxidation stability in a thin layer & $\min$ & 364 & 164 & 157 & ASTM D $4742^{*}$ \\
\hline $\begin{array}{l}\text { Package elements content: } \\
\text { - zinc } \\
\text { - calcium } \\
\text { - magnesium } \\
\text { - phosphorus }\end{array}$ & ppm & $\begin{array}{r}902.0 \\
3017.0 \\
24.0 \\
674.0\end{array}$ & $\begin{array}{r}838.0 \\
2575.0 \\
12.9 \\
655.0\end{array}$ & $\begin{array}{r}787.0 \\
2787.0 \\
14.8 \\
616.0\end{array}$ & \multirow{13}{*}{ ASTM D 5185} \\
\hline $\begin{array}{l}\text { Content of elements from wear and pollution: } \\
\text { - iron }\end{array}$ & \multirow{12}{*}{ ppm } & 15 & 13 & 17 & \\
\hline - aluminium & & less than 6.0 & $\begin{array}{l}\text { less than } 6.0 \\
(3.1)\end{array}$ & $\begin{array}{l}\text { less than } 6.0 \\
(3.2)\end{array}$ & \\
\hline - copper & & less than 2.0 & $\begin{array}{l}\text { less than } 2.0 \\
(0.85)\end{array}$ & $\begin{array}{l}\text { less than } 2.0 \\
\quad(0.98)\end{array}$ & \\
\hline- lead & & less than 10 & $\begin{array}{l}\text { less than } 10 \\
\text { (0) }\end{array}$ & $\begin{array}{l}\text { less than } 10 \\
\qquad(0.13)\end{array}$ & \\
\hline - barium & & less than 0.5 & $\begin{array}{l}\text { less than } 0.5 \\
\quad(0.01)\end{array}$ & $\begin{array}{l}\text { less than } 0.5 \\
\quad(0.03)\end{array}$ & \\
\hline - chromium & & less than 1.0 & $1.8 \pm 0.8$ & $1.6 \pm 0.8$ & \\
\hline - potassium & & less than 10 & $\begin{array}{l}\text { less than } 10 \\
(1.8)\end{array}$ & $\begin{array}{l}\text { less than } 10 \\
(4.8)\end{array}$ & \\
\hline - molybdenum & & 49 & $79 \pm 10$ & $103 \pm 12$ & \\
\hline - sodium & & less than 7.0 & $7.1 \pm 3.2$ & $\begin{array}{l}\text { less than } 7.0 \\
(4.1)\end{array}$ & \\
\hline - nickel & & less than 5.0 & $\begin{array}{l}\text { less than } 5.0 \\
\qquad(0.05)\end{array}$ & $\begin{array}{l}\text { less than } 5.0 \\
\qquad(0.08)\end{array}$ & \\
\hline - silicon & & 153 & $43 \pm 9$ & 150 & \\
\hline$-\operatorname{tin}$ & & less than 10 & $\begin{array}{l}\text { less than } 10 \\
(0.62)\end{array}$ & $\begin{array}{l}\text { less than } 10 \\
(0.74)\end{array}$ & \\
\hline
\end{tabular}

\footnotetext{
${ }^{*}$ Modified method (E85 ethanol fuel consisting of 15\% $(V / V)$ base petrol and of $85 \%(V / V)$ fuel ethanol was used a the fuel catalyst).
} 
A drastic drop of oxidation resistance not entirely has converted into the decline of determined zinc content. For sample 1 it went down only by approx. $7 \%$, and for sample 2 by approx. $13 \%$ against the value determined for its level (902 ppm) determined for the fresh oil sample (Figure 9).

The difference in results obtained by the aforementioned research methods can be related to the applied modifications to the ASTM D 4742 method and in the further research the present results should be referred to those, which will be determined in accordance with guidelines of the standard.

The degradation processes of engine lubricating oil result in the formation of substances acid in nature, which action is neutralised due to additives, featuring an alkaline reserve (i.e. detergents), possessed by the engine oil. During the operation those additives are depleted, which is observed via a decline of total base number and an increase in the acid number. In addition, the total base number characterises also a washing-dispersing potential of the tested engine oil. The task of washing additives (detergents) consists in maintaining engine surfaces clean, in neutralising acidic products formed as a result of fuel combustion, i.e. $\mathrm{SO}_{\mathrm{x}}$ and $\mathrm{NO}_{\mathrm{x}}$, and in preventing precipitation from the engine oil of solid deposits on the lubricated engine surfaces. The content of those additives is monitored just on the basis of total base number, and also based on the determination of calcium and magnesium content. The total base number determined for sample 1 went down by approx. $26 \%$ against the value determined for the fresh oil sample (a decline by approx. $25 \%$ is the permissible limit value for this parameter). The washing-dispersing properties deteriorated during the operation, which is also confirmed by a drop in the calcium (a decrease by approx. 15\% against the fresh oil) and in the magnesium content (a decline by approx. $46 \%$ against the fresh oil). Instead, the total base number determined for sample 2 went down by approx. 30\% against the value determined for the fresh oil sample (a decline by approx. $25 \%$ is the permissible limit value for this parameter). The washing-dispersing properties deteriorated during the operation, which is also observed based on a determined drop in the calcium (a decrease by approx. $8 \%$ against the non-operated oil) and in the magnesium content (a decline by approx. 38\% against the fresh oil) (Figures 7, 8).

Also the content of metallic elements, originating from the wear of engine frictional connections and from the environmental pollution getting to the system from outside, was determined in the tested samples of engine lubricating oils. The determined, almost unchanged levels of those elements in both tested samples after $300 \mathrm{~h}$ of operation prove that the tested samples of engine oils retained the function and protection of frictional connections against wear during the engine operation.

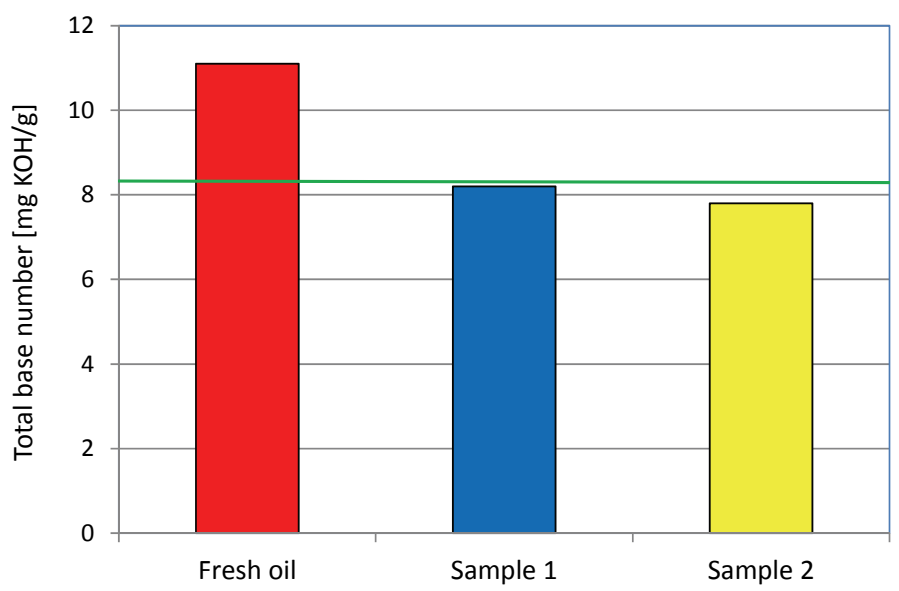

Fig. 7. Change of total base number for SAE $5 \mathrm{~W}-30$ engine oil samples (green line - minimum limit value)

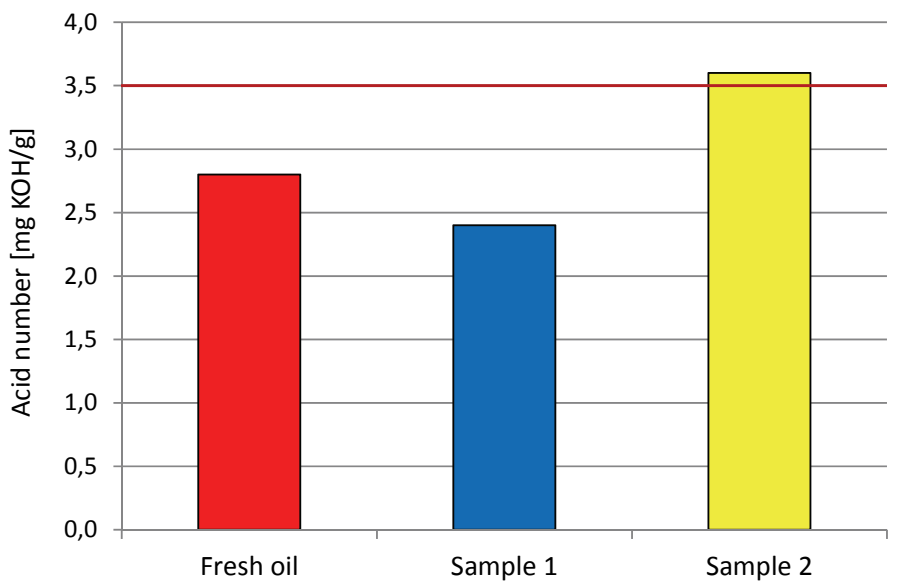

Fig. 8. Change of acid number for SAE 5W-30 engine oil samples (red line - maximum limit value)

This is confirmed by the determined high level of phosphorus originating probably from anti-seizing up additives (EP type) (reduction by only approx. $3 \%$ for sample 1 and by approx. $9 \%$ for sample 2 against the level of $674 \mathrm{mg} / \mathrm{kg}$ determined for the fresh oil) (Figures 9, 10, 11).

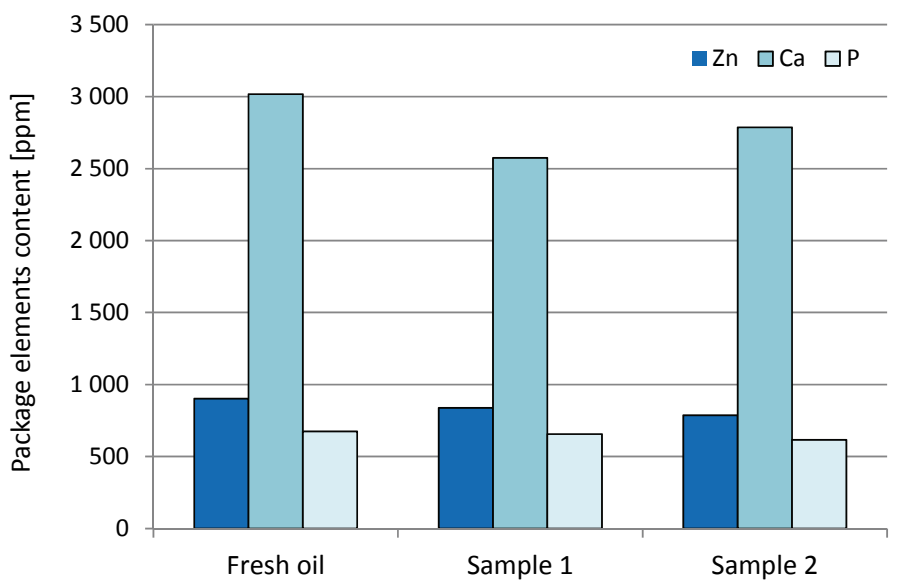

Fig. 9. Change of zinc, calcium, and phosphorus content for SAE 5W-30 engine oil samples 


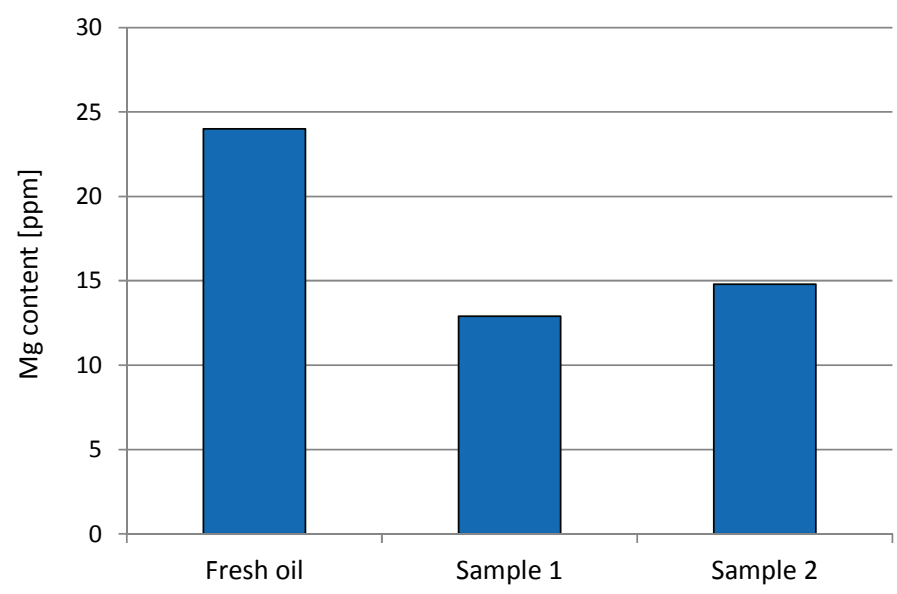

Fig. 10. Change of magnesium content for SAE 5W-30 engine oil samples

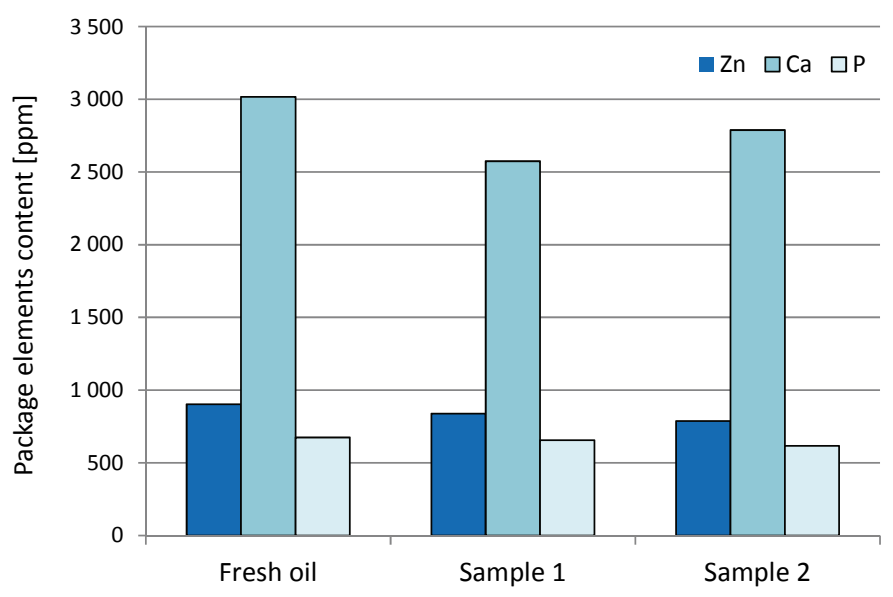

Fig. 11. Change of elements, originating from wear and from system pollution, content for SAE $5 \mathrm{~W}-30$ engine oil samples

\section{Summary}

Summarising the obtained results of tests it is possible to state that no significant influence of the type of used hydrocarbon petrol on selected physicochemical and practical properties of engine lubricating oil being the subject of tests. The engine oil after a test with an unleaded engine petrol originating from a refinery of developed petroleum processing (Fuel 2) has shown slightly better properties in the field of rheological parameters.

The tested samples of engine oils collected after $300 \mathrm{~h}$ of flex fuel type engine operation retained their rheological properties on levels corresponding to $5 \mathrm{~W}-30$ viscosity class. In both tested cases the engine oil degraded, what was observed by depletion of package additives and by determination of oxidation, nitration, and sulphonation degree. But they proceed mildly, typically for a proper engine operation.

As a result of degradation processes the content of acidic substances has increased, which was confirmed by a growth of the acid number and simultaneous reduction of alkaline reserve (a decline of total base number).

The research methods selected to assess the degree of degradation enabled to monitor fully changes of physicochemical and practical properties of engine lubricating oil occurring during its operation.

Please cite as: Nafta-Gaz 2018, no. 4, pp. 308-318, DOI: 10.18668/NG.2018.04.07

Article contributed to the Editor 13.11.2017. Approved for publication 5.03.2018.

The article was written on the basis of a research work entitled: Studying the issues of ethanol fuels interaction with the engine and with lubricating oil during operation - INiG - PIB work commissioned by the Ministry of Science and Higher Education; order no.: 0116/TE/17, archival no.: DK-4100-0116/17.

\section{Literature}

[1] Ansomboon J., Wutimongkolchai A., Pannoo S., Fukada K.: Characterization of Deposits and Effects of Detergent Additive, Olefin Content and Engine on Intake Valve Deposit Formation. Petroleum Authority of Thailand and Japan International Cooperation Agency, SAE Paper no. 2000-01-2856, 2000.

[2] Baczewski K., Kałdoński T.: Paliwa do silników o zapłonie iskrowym. Wydawnictwo Komunikacji i Łączności, Warszawa 2005.

[3] Danek B.: Wptyw właściwości frakcji benzynowych na parametry składu frakcyjnego paliwa etanolowego E85. Nafta-Gaz 2012, no. 10, pp. 708-713.

[4] Danek B.: Zmiany właściwości określajacych stabilność chemiczna biopaliwa E85 podczas jego magazynowania. Nafta-Gaz 2011, no. 8, pp. 577-580.

[5] Eriksson M.: The oil temperature's effects on engine oil degradation in trucks. KTM Industrial Engineering and Management, Master of Science Thesis, Stockholm, Sweden 2007.
[6] Giżyński P., Bętlejewski M., Tomaszewski J.: Produkcja benzyn silnikowych $w$ rafinerii płockiej. Biuletyn Instytutu Technologii Nafty 2005, vol. XVII, no. 3, pp. 166-173.

[7] Homan S.H., Keleman S.R.: The effect of gasoline additive, automobile make and driving cycle on intake valve and combustion chamber deposits (CCD) in ten car fleet tests. SAE Paper no. 972836, 1997.

[8] Kim C., Cheng S., Majorski S.A.: Engine Combustion Chamber Deposits: Fuel Effects and Mechanisms of Formation. SAE Paper no. 912379, 1991.

[9] Maćkowski J.: Wplyw benzyny na zanieczyszczenie silnikaczęść 1. Paliwa, Oleje i Smary w Eksploatacji 2003, no. 106, pp. 25-32.

[10] Maćkowski J.: Wptyw benzyny na zanieczyszczenie silnikaczęść 2. Paliwa, Oleje i Smary w Eksploatacji 2003, no. 107, pp. 33-38.

[11] Maćkowski J.: Wplyw benzyny na zanieczyszczenie silnika- 
część 3. Paliwa, Oleje i Smary w Eksploatacji 2003, no. 108, pp. 31-35.

[12] Maćkowski J.: Wplyw benzyny na zanieczyszczenie silnikaczesść 4. Paliwa, Oleje i Smary w Eksploatacji 2003, no. 109, pp. 29-33.

[13] Maćkowski J.: Wpływ benzyny na zanieczyszczenie silnika czesść 5. Paliwa, Oleje i Smary w Eksploatacji 2003, no. 110, pp. 15-23.

[14] Maćkowski J.: Wpływ benzyny na zanieczyszczenie silnika część 6. Paliwa, Oleje i Smary w Eksploatacji 2003, no. 111, pp. 25-31.

[15] Maćkowski J.: Wpływ benzyny na zanieczyszczenie silnika czesść 7. Paliwa, Oleje i Smary w Eksploatacji 2003, no. 112, pp. 25-35.

[16] Maćkowski J.: Wpływ benzyny na zanieczyszczenie silnika część 8. Paliwa, Oleje i Smary w Eksploatacji 2003, no. 113, pp. 25-35.

[17] Marshal E.L., Owen K.: Motor Gasoline; The College of Petroleum and Energy Studies, Oxford, UK; The Royal Society of Chemistry, 1995

[18] Martin P., Mendez A.: Mechanisms of gasoline deposit formation in engine induction systems. Characterization of product reaction between benzothiophene oxides and benzothiophenes. Petroleum Science and Technology 1997, vol. 15, no. 1-2, pp. 1-18.

[19] Megnin M.K., Furman J.B.: Gasoline Effects on Octane Requirement Increase and Combustion Chamber Deposits. SAE Paper no. 922258, 1992.

[20] Owen K., Coley T.: Automotive fuels handbook. Published by Society of Automotive Engineers, Inc., 1990.

[21] Pałuchowska M.: Wplyw rafineryjnej formuly komponentowej paliw etanolowych na ich parametry fizykochemiczne i użyt- kowe. Prace Naukowe Instytutu Nafty i Gazu - Państwowego Instytutu Badawczego 2012, 146 pp.

[22] Ping W.D., Korcek S., Spikes H.: Comparison of the Lubricity of Gasoline and Diesel Fuels. SAE Paper no. 962010, 1996.

[23] Price M.J.: The Development of Specifications for Automotive Fuels. Biuletyn Instytut Technologii Nafty 2003, vol. XV, no. 1, pp. 78-87.

[24] Shifrin G.G., Gureev A.A., Sokolov V.V., Kitskii B.P.: Qualification Test Methods for Evaluation of Tendency of Automotive Gasoline to form Combustion Chamber Deposits. Plenum Publishing Corporation 1983.

[25] Uehara T., Takei Y., Hoshi H., Shiratani K., Okada M.: Study on Combustion Chamber Deposit Formation Mechanism Influence of Fuel Components and Gasoline Detergents. SAE Paper no. 971722, 1997.

\section{Legal and normative acts}

[26] ASTM D 4814 Standard Specification for Automotive SparkIgnition Engine Fuel.

[27] Directive 2009/28/WE z dn. 23.04.2009 (Dz.U. UE L 09.140.16); http://www.certyfikacja-biopaliw.pl/2009_28.pdf (access: 21.05.2017).

[28] Norma PN-EN 15376 Paliwa do pojazdów samochodowychEtanol jako komponent benzyny silnikowej - Wymagania i metody badań, 2014.

[29] Norma PN-EN 228 Paliwa do pojazdów samochodowych - Benzyna bezołowiowa - Wymagania i metody badań, 2012.

[30] Rozporządzenie Ministra Gospodarki z dnia 22 stycznia 2009 r. w sprawie wymagań jakościowych dla biopaliw ciekłych określa wymagania jakościowe, jakie musi spełniać paliwo silnikowe E85.

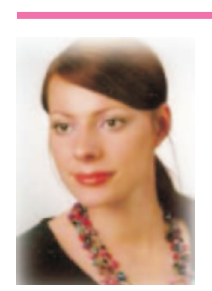

Magdalena ŻÓŁTY PhD Eng.

Research and technical specialist in the Department of Evaluation of Operational Properties.

Oil and Gas Institute - National Research Instituteul.

Lubicz 25 A, 31-503 Kraków

E-mail:magdalena.zolty@inig.pl

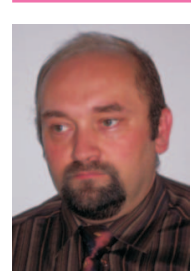

Dariusz SACHA M.Sc. Eng.

Senior Technical and Research Specialist in the Department of Evaluation of Operational Properties Oil and Gas Institute - National Research Institute ul. Lubicz 25 A

31-503 Kraków

E-mail: dariusz.sacha@inig.pl 